\title{
PENINGKATAN HASIL BELAJAR IPA MELALUI MODEL PEMBELAJARAN KOOPERATIF TIPE STAD DI KELAS VII-7 SMP NEGERI 1 BANGUN PURBA
}

\author{
Pujien Barus \\ Guru IPA SMP Negeri Bangun Purba \\ Surel : Rizkiandriani21@yahoo.com
}

\begin{abstract}
Abstrak
Penelitian ini bertujuan untuk melihat aktivitas belajar siswa yang mencakup aktivitas belajar siswa saat bekerja dalam kelompok dikelas pada mata pelajaran IPA dan juga prestasi belajar siswa dengan menerapkan model pembelajaran kooperatif tipe STAD. Awal KBM dilakukan tes hasil belajar (Pretes), dengan data rata-rata 32,3. Kemudian dilanjutkan KBM, akhir KBM ke II dan KBM ke IV dilakukan tes hasil belajar formatif I dan formatif II hasilnya masing-masing menunjukkan rata-rata 68,57 dan 85,14 . Ada perubahan akibat tindakan guru selama KBM pada siklus II. Data aktivitas siswa menurut pengamatan pengamat pada siklus I antara lain membaca/menulis (42\%), bekerja (27\%), bertanya sesama teman $(5,6 \%)$, bertanya kepada guru $(13,8 \%)$, dan yang tidak relevan dengan KBM (12\%). Data aktivitas siswa menurut pengamatan pada siklus II antara lain membaca/menulis $(25,8 \%)$, bekerja $(52,6 \%)$, bertanya sesama teman $(14,2 \%)$, bertanya kepada guru (3\%), dan yang tidak relevan dengan KBM $(4,2 \%)$.
\end{abstract}

Kata Kunci: Model Pembelajaran Kooperatif, Hasil Belajar

\section{PENDAHULUAN}

Ilmu Pengetahuan Alam

(IPA) merupakan konsep

pembelajaran alam dan mempunyai

hubungan yang sangat luas terkait dengan kehidupan manusia.

Pembelajaran IPA sangat berperan dalam proses pendidikan dan juga perkembangan Teknologi.

Pembelajaran IPA diharapkan bisa menjadi wahana bagi siswa untuk mempelajari diri sendiri dan alam sekitar, serta pengembangan lebih lanjut dalam penerapan dalam kehidupan sehari-hari.

Siswa sebagai subjek pendidikan, di tuntut supaya aktif dalam belajar mencari informasi dan mengeksplorasi sendiri atau secara berkelompok. Guru hanya berperan sebagai fasilitator dan pembimbing kearah pengoptimalan pencapaian ilmu pengetahuan yang dipelajari. Diharapkan dalam proses pembelajaran siswa mau dan mampu mengemukakan pendapat sesuai dengan apa yang telah dipahami, berinteraksi secara positif antara siswa dengan siswa maupun antara siswa dan guru apabila ada kesulitan. Kenyataannya, peneliti sendiri sebagai guru mata pelajaran IPA di kelas VII-7 SMP Negeri 1 Bangun Purba memiliki masalah dalam mengajarkan mata pelajaran IPA kepada siswa.

Aktivitas yang ditunjukkan siswa pada pembelajaran masih rendah seperti rendahnya minat siswa belajar kelompok 
dimana pelaksanaan pembelajaran di lapangan melalui belajar kelompok masih jarang, jika ada dilaksanakan hasil yang di capai masih rendah. Pada umumnya siswa cenderung pasif, hanya menerima apa yang di sampaikan guru tanpa bisa mengeluarkan pendapat, bertanya, serta menjawab pertanyaan. Jika guru mengajukan pertanyaan, siswa tidak berani menjawab, jika ada itu hanya 4-5 orang siswa saja. Dan jika ada kendala siswa tidak berani bertanya. Dan nilai yang di peroleh siswa masih di bawah standar ketuntasan belajar, dimana standar yang di gunakan adalah 65 . Namun masih terdapat $60 \%$ dari siswa dalam pembelajaran IPA mendapat nilai di bawah standar yaitu ( $25-60)$.

Berdasarkan hasil diskusi peneliti dengan sesama peneliti dan juga tutor dari LPMP dan UNIMED dan pendamping peneliti dari UNIMED maka peneliti memutuskan untuk menerapkan model pembelajaran kooperatif tipe STAD. STAD (Student Team Achivement Division) merupakan salah satu metode pembelajaran kelompok yang paling awal ditemukan. Metode ini sangat populer dikalangan para ahli pendidikan. Dalam metode STAD siswa dipasangkan secara merata yang memiliki kemampuan tinggi dan rendah dalam suatu kelompok sebanyak $4-5$ orang. Skor kelompok diberikan berdasarkan atas prestasi anggota kelompoknya. Ciriciri yang penting dalam STAD adalah bahwa siswa dihargai atas prestasi kelompok dan juga terhadap semangat kelompok untuk bekerjasama.

Menurut Slavin (dalam Nurasma, 2008 : 1) “ Cooperative learning methods share the idea that students work together to learn and are responsible for their teammates learning as their own" yang berarti bahwa dalam belajar kooperatif siswa belajar bersama, saling menyumbang pemikiran dan bertanggung jawab terhadap pencapaian hasil belajar secara individu maupun kelompok".

Dari pendapat di atas dapat di simpulkan bahwa model pembelajaran tipe STAD adalah model pembelajaran kelompok dengan anggota yang heterogen untuk mencapai tujuan pembelajaran. Model STAD ini membantu dan memotivasi semangat siswa untuk berhasil memecahkan suatu masalah secara bersama. Model Pembelajaran kooperatif tipe STAD merupakan model yang paling sederhana, sehingga model pembelajaran tersebut dapat di gunakan oleh guruguru yang baru memulai menggunakan model pembelajaran kooperatif.

Pada pembelajaran kooperatif tipe STAD siswa di tuntut untuk bekerja sama, dengan bekerja sama siswa akan lebih mudah memahami materi tersebut karena melalui belajar dari teman sebaya dan di bawah bimbingan guru, maka proses penerimaan dan pemahaman siswa akan semakin mudah dan cepat terhadap materi yang di pelajari. Hal 
ini di dukung oleh pendapat Nur Asma (2008:3) bahwa " Siswa lebih mudah menemukan dan memahami suatu konsep jika mereka saling mendiskusikan masalah tersebut dengan temannya". Selanjutnya Ari (2007:96) berpendapat bahwa "Anak-anak lebih mengerti bahasa anak daripada bahasa yang digunakan oleh orang dewasa".

Dari latar belakang yang telah diuraikan diatas, maka indentifikasi masah, yaitu: 1) siswa kurang terlibat dalam proses pembelajaran, 2) guru jarang menggunakan media motivasi belajar siswa masih rendah, 3) pemahaman siswa terhadap konsep IPA masih rendah akibat siswa tidak memiliki buku pegangan lain selain buku pelajaran, 4) guru cenderung menggunakan metode pembelajaran konvensional, 4) hasil belajar IPA siswa cukup rendah. Dari indentifikasi maka didapat rumusan masalah yaitu, 1) apakah model pembelajaran kooperatif tipe STAD dapat meningkatkan hasil belajar siswa pada materi pokok materi pokok ekosistem di kelas VII-7 SMP Negeri 1 Bangun Purba? 2) Apakah model pembelajaran kooperatif tipe STAD dapat meningkatkan aktivitas belajar siswa pada materi pokok ekosistem di kelas VII-7 SMP Negeri 1 Bangun Purba?

Adapun tujuan penelitian tersebut adalah 1) untuk mengetahui apakah hasil belajar siswa meningkat melalui penerapan model pembelajaran kooperatif tipe STAD pada materi pokok magnet di kelas
VII-7 SMP Negeri 1 Bangun Purba, 2) Untuk mengetahui apakah aktivitas belajar siswa meningkat melalui penerapan model pembelajaran kooperatif tipe STAD pada materi pokok ekosistem di kelas VII-7 SMP Negeri 1 Bangun Purba.

\section{METODOLOGI PENELITIAN}

Penelitan ini termasuk dalam jenis Penelitian Tindakan Kelas. Penelitian Tindakan Kelas (PTK) yakni suatu pencermatan terhadap suatu kegiatan yang sengaja dimunculkan, dan terjadi di dalam sebuah kelas ( Suharsimi Arikunto, dkk : 16: 2007 ). Hal-hal yang perlu dipersiapkan sebelum melakukan penelitian adalah memilih model pembelajaran yang dinilai sesuai dengan materi yang akan disampaikan. Dalam hal ini peneliti memilih menerapkan model pembelajaran kooperatif tipe STAD yang kemudian membuat satuan pelajaran, rencana pelajaran dan perangkat pembelajaran (LKS, buku siswa, dll).

\section{A. Lokasi dan Waktu Penelitian}

Tempat penelitian tindakan kelas ini adalah di SMP Negeri 1 Bangun Purba di Jalan Sinsingamangaraja Kecamatan Bangun Purba kelas VII7. Dan waktu penyelenggaraan penelitian ini adalah pada semester II (genap) mulai dari bulan Maret 2015 sampai dengan Juli 2015. 


\section{B. Subjek Penelitian}

Subjek penelitian tindakan kelas ini adalah siswa kelas VII-7 yang berjumlah 35 orang siswa. Adapun yang bertindak sebagai observer dalam penelitian ini adalah guru teman sejawat yaitu Amir Girsang, S.Pd dan Erhaini Purba, S.Pd.

\section{Siklus Penelitian}

Penelitian Tindakan Kelas (PTK) ini dilakukan dalam 2 siklus, sesuai dengan waktu yang telah direncanakan, yakni 8 jam pelajaran untuk pokok bahasan sebagai berikut:

a. Materi pembelajaran siklus I: Pengertian dan komponenkomponen ekosistem(KBM 1) dan Macam dan satuan dalam ekosistem (KBM 2)

b. Materi Pembelajaran siklus II: Rantai dan jaring - jaring makanan (KBM 3) dan Pola interaksi dalam ekosistem (KBM 4)

Pada tiap putaran terdiri atas 4 tahap, yaitu : rancangan, kegiatan dan pengamatan, refleksi, revisi.

\section{Instrumen Penelitian}

Alat pengumpul data dalam penelitian ini adalah tes berbentuk pilihan berganda, dan lembar observasi Tes hasil belajar ini digunakan untuk mengetahui kemampuan siswa pada tingkat kognitif dan observasi untuk mengetahui aktivitas belajar siswa setelah menerapkan model pembelajaran kooperatif tipe STAD.

Adapun materi pokok dalam penelitian dijabarkan dalam tabel 1 .

Tabel 1 : Tabel Spesifikasi Materi Pokok Ekosistem

\begin{tabular}{|l|l|c|c|c|c|}
\hline No & Indikator & $\begin{array}{c}\text { Bentuk } \\
\text { soal }\end{array}$ & $\begin{array}{c}\text { No. } \\
\text { Soal }\end{array}$ & $\begin{array}{c}\text { Tingkat } \\
\text { Kognitif }\end{array}$ & Skor \\
\hline 1. & $\begin{array}{l}\text { Menjelaskan pengertian } \\
\text { ekosistem }\end{array}$ & PG & 1 & $\mathrm{C}_{1}$ & 1,1 \\
\hline 2. & $\begin{array}{l}\text { Mengelompokkan } \\
\text { komponen ekosistem }\end{array}$ & PG & 3,4 & $\mathrm{C}_{2, \mathrm{C} 2}$ & 1 \\
\hline 3. & $\begin{array}{l}\text { Mengelompokan } \\
\text { macam-macam } \\
\text { ekosistem }\end{array}$ & $\mathrm{PG}$ & 5 & $\mathrm{C}_{4}$ & 1 \\
\hline 4. & $\begin{array}{l}\text { Mengejelaskan satuan- } \\
\text { satuan ekosistem }\end{array}$ & $\mathrm{PG}$ & 2 & $\mathrm{C}_{2}$ & 1 \\
\hline 5. & $\begin{array}{l}\text { Menjelaskan rantai dan } \\
\text { jaring-jaring makanan }\end{array}$ & $\mathrm{PG}$ & 6,7, & $\mathrm{C}_{2, \mathrm{C} 2, \mathrm{C}}$ & 1,1, \\
\hline 6. & $\begin{array}{l}\text { Menjelaskan pola } \\
\text { interaksi PG dalam } \\
\text { ekosisitem }\end{array}$ & 9,10 & $\mathrm{C} 3, \mathrm{C} 3$ & 1,1 \\
\hline
\end{tabular}

Keterangan :

$\mathrm{C}_{1}$ : Pengetahuan

$\mathrm{C}_{2}$ : Pemahaman

$\mathrm{C}_{3}$ : Aplikasi

$\mathrm{C}_{4}$ : Analisis

\section{E. Analisis Dan Refleksi}

a. Metode pengumpulan data, yaitu: Observasi dan Metode Tes.

b. Metode Analisis Data

Dalam penelitian ini analisis data yang digunakan adalah analisis deskriptif kualitatif. Data yang dianalisis ini adalah nilai tes belajar siswa pada materi pokok ekosistem dan data pengamatan aktivitas belajar siswa dalam kegiatan belajar mengajar. Analisis data yang digunakan adalah sebagai berikut:

a. Data hasil ketuntasan belajar siswa

Secara individual, siswa telah tuntas belajar jika mencapai skor..\% atau nilai ..dengan perhitungan sebagai beriktu (Depdikbud, 1994): 
SkorSiswa $=\frac{\text { Skor yang diperoleh }}{\text { Skormaksimum }} \times 100 \%$

Suatu kelas dinyatakan tuntas belajar jika terdapat $\geq 85 \%$ dari jumlah siswa telah tuntas belajar. Perhitungan untuk menyatakan ketuntasan belajar siswa secara klasikal:

$=\frac{\text { jumlahsiswa yangtuntas }}{\text { jumlahsiswa seluruhnya }} \times 100 \%$

b. Data hasil pengamatan aktivitas guru dan aktivitas siswa. Observasi terhadap aktivitas siswa dilakukan selama pembelajaran berlangsung selang 2 menit. Hasil observasi dianalisis dengan jumlah aktivitas siswa yang dilakukan dibagi jumlah siswa yang melakukan aktivitas dibagi waktu keseluruhan dikali $100 \%$. Untuk penilaian aktivitas digunakan rumus sebagai berikut:

\% Proporsi Aktivitas

$=\frac{\text { jumlah skor yang diperoleh }}{\text { jumlah skor ideal }} \times 100 \%$

(Majid, 2009:268)

c. Ketentuan persentase ketuntasan belajar kelas

Ketuntasan belajar kelas $=\frac{\sum S_{b}}{K} \times 100 \%$

Keterangan:

$\Sigma$ Sb: Jumlah siswa yang mendapat nilai $\geq 70$ (kognitif)

$\Sigma \mathrm{K}$ : Jumlah siswa dalam sampel
Sebagai tolak ukur keberhasilan penelitian tindakan kelas ini dapat dilihat dari: hasil tes, jika hasil belajar siswa mencapai KKM secara individual dan $85 \%$ secara klasikal.

\section{HASIL PENELITIAN DAN PEMBAHASAN}

A. Hasil Penelitian

Pra Siklus

Sebelum melaksanakan siklus I maka terlebih dahulu peneliti mengumpulkan data untuk melihat kondisi siswa sebelum dilakukan penelitian. Adapun pengumpulan data yakni dengan memberikan uji pretes kepada siswa. Data yang diperoleh yakni tidak seorangpun siswa mendapat nilai di atas KKM 70, dengan ketuntasan klasikal 0\% dan rata-rata nilai 32,3 .

\section{Siklus I}

Pada siklus I didapat hasil cukup memuaskan dengan nilai ratarata kelas 64. Akhir Siklus I dilakukan tes hasil belajar atau disebut Formatif I, dengan data dapat dilihat Pada Tabel 2. Merujuk pada kesimpulan ini guru sebagai peneliti berusaha memperbaiki proses dan hasil belajar siswa Melalui Model Pembelajaran Kooperatif Tipe STAD. Hasil belajar yang diperoleh pada siklus I selama dua pertemuan disajikan dalam Tabel berikut:

Tabel 2. Distribusi Hasil Formatif I

\begin{tabular}{|l|l|l|l|l|}
\hline Nilai & Frekuensi & $\begin{array}{c}\text { Tuntas } \\
\text { Individu }\end{array}$ & $\begin{array}{c}\text { Tuntas } \\
\text { Kelas }\end{array}$ & $\begin{array}{c}\text { Nilai } \\
\text { rata- } \\
\text { rata }\end{array}$ \\
\cline { 1 - 4 } 40 & 8 & - & - & \\
\cline { 1 - 4 } 60 & 14 & - & - & \\
\cline { 1 - 4 } 80 & 23 & 23 & $65,71 \%$ & \multirow{2}{*}{68,57} \\
\hline Jumlah & 35 & 23 & $65,71 \%$ & 68,57 \\
\hline
\end{tabular}


Pada Tabel 2 tersebut, nilai terendah formatif I adalah 40 sebanyak 8 orang dan nilai tertinggi adalah 80 sebanyak 23 orang, dengan 23 orang mendapat nilai dibawah kriteria ketuntasan atau ketuntasan klasikal adalah sebesar $65,71 \%$. Dengan nilai KMM sebesar 70 nilai ini berada sedikit di bawah kriteria keberhasilan klasikal sehingga dapat dikatakan KBM siklus I kurang berhasil memberi ketuntasan belajar dalam kelas.

Aktivitas Belajar diperoleh dari lembar observasi aktivitas. Pengamatan dilakukan oleh dua pengamat selama 20 menit kerja kelompok dalam setiap KBM atau 40 menit dalam satu siklus. Adapun data aktivitas yang diperoleh selama 40 menit pada siklus I adalah sebagai berikut :

Tabel 3. Skor Aktivitas Belajar Siswa

\begin{tabular}{|c|c|c|c|c|}
\hline \multicolumn{5}{|c|}{ Siklus I } \\
\hline No & Aktivitas & Jumlah & $\begin{array}{l}\text { Rata- } \\
\text { Rata }\end{array}$ & Persentase \\
\hline 1 & $\begin{array}{l}\text { Menulis, } \\
\text { Membaca }\end{array}$ & 67 & 16,75 & $42 \%$ \\
\hline 2 & Mengerjakan & 43 & 10,75 & $27 \%$ \\
\hline 3 & $\begin{array}{l}\text { Bertanya pada } \\
\text { teman }\end{array}$ & 9 & 2,25 & $5,6 \%$ \\
\hline 4 & $\begin{array}{l}\text { Bertanya pada } \\
\text { guru }\end{array}$ & 22 & 5,5 & $13,8 \%$ \\
\hline 5 & $\begin{array}{l}\text { Yang tidak } \\
\text { Relevan }\end{array}$ & 19 & 4,75 & $12 \%$ \\
\hline & Jumlah & 160 & 40 & $100 \%$ \\
\hline
\end{tabular}

\section{Siklus II}

Data-data Formatif I dianalisis, sehingga mendapat suatu gambaran tentang keberhasilan siswa. Untuk memperbaiki hasil belajar siswa, peneliti memberikan suatu gambaran hasil belajar siswa pada Formatif I sesama peneliti/guru kemudian didiskusikan untuk mengambil tindakan berikutnya pada Siklus II. Diskusi tersebut juga dilakukan terhadap pembimbing PTK agar pada tindakan berikutnya aktivitas siswa semakin baik dan hasil belajarnya juga lebih baik.

Uraian di atas menyatakan bahwa pada Siklus I indikator keberhasilan belum tercapai karena terdapat 12 siswa yang belum tuntas nilainya. Oleh karena itu perlu adanya suatu tindakan pada Siklus II agar hasil belajar siswa dapat ditingkatkan dan mencapai indikator keberhasilan dengan ketuntasan klasikal mencapai maksimum. Akhir KBM ke empat dilakukan tes hasil belajar atau disebut Formatif II, datanya dapat dilihat Pada Tabel 4.

Tabel 4. Distribusi Hasil Formatif II

\begin{tabular}{|c|c|c|c|c|}
\hline Nilai & Frekuensi & $\begin{array}{c}\text { Tuntas } \\
\text { Individu }\end{array}$ & $\begin{array}{l}\text { Tuntas } \\
\text { Kelas }\end{array}$ & $\begin{array}{l}\text { Rata- } \\
\text { rata }\end{array}$ \\
\hline 60 & 4 & - & - & \multirow{4}{*}{85,14} \\
\hline 80 & 18 & 18 & $51,42 \%$ & \\
\hline 100 & 13 & 13 & $37,14 \%$ & \\
\hline Jumlah & 35 & 31 & $87,56 \%$ & \\
\hline
\end{tabular}

Merujuk pada Tabel 4. nilai terendah untuk Formatif II adalah 60 sebanyak 4 orang dan tertinggi adalah 100 sebanyak 13 orang. Dengan 4 orang mendapat nilai dibawah kriteria ketuntasan atau ketuntasan klasikal adalah sebesar $87,56 \%$. Nilai ini berada di atas kriteria keberhasilan sehingga dapat dikatakan KBM Siklus II berhasil memberi ketuntasan belajar dalam 
kelas. Nilai rata-rata kelas adalah 85,14 .

Data aktivitas siswa selama kegiatan belajar mengajar dapat dilihat pada tabel di bawah ini :

Tabel 5. Skor Aktivitas Belajar Siswa

\begin{tabular}{|c|c|c|c|c|}
\hline \multicolumn{5}{|c|}{ Siklus II } \\
\hline No & Aktivitas & Jumlah & $\begin{array}{l}\text { Rata- } \\
\text { Rata }\end{array}$ & Persentase \\
\hline 1 & $\begin{array}{l}\text { Menulis dan } \\
\text { Membaca }\end{array}$ & 49 & 12,25 & $25,8 \%$ \\
\hline 2 & Mengerjakan & 100 & 25 & $52,6 \%$ \\
\hline 3 & $\begin{array}{l}\text { Bertanya pada } \\
\text { teman }\end{array}$ & 27 & 6,75 & $14,2 \%$ \\
\hline 4 & $\begin{array}{l}\text { Bertanya pada } \\
\text { guru }\end{array}$ & 6 & 1,5 & $3 \%$ \\
\hline 5 & $\begin{array}{l}\text { Yang tidak } \\
\text { relevan }\end{array}$ & 8 & 2 & $4,2 \%$ \\
\hline & Jumlah & 200 & 47,5 & $100 \%$ \\
\hline
\end{tabular}

\section{B. Pembahasan}

Dari data hasil penelitian yang telah tersaji pada tabel 2, 3, 4 dan 5. Dari data tabel 4.1 dan 4.3 terjadi peningkatan aktivitas belajar siswa. pada siklus I aktivitas belajar siswa sebagai berikut: aktivitas menulis dan membaca $42 \%$, aktivitas mengerjakan LKS 27\%, aktivitas bertanya pada teman $5,6 \%$, aktivitas bertanya pada guru $13,8 \%$, aktivitas yang tidak relevan dengan KBM 12\%. Pada siklus II, aktivitas menulis dan membaca turun menjadi $25,8 \%$ yang mengindikasikan siswa sudah mempersiapkan diri dari rumah sehingga siswa tidak lagi perlu banyak membaca di sekolah pada saat pelaksanaan diskusi, hal ini juga mengindikasikan turunnya tindakan individual siswa. Aktivitas mengerjakan LKS pada siklus II mengalami peningkatan yang cukup pesat yakni dari $27 \%$ menjadi 52,6
\%. Hal ini menunjukkan bahwa siswa menjadi lebih aktif dalam mengerjakan LKS. aktivitas bertanya kepada teman mengalami peningkatan menjadi $14,2 \%$, hal ini menunjukkan siswa menjadi lebih kooperatif dan lebih bekerjasama dengan temannya, sehingga aktivitas bertanya meningkat. Aktivitas bertanya pada guru mengalami penurunan dari $13,8 \%$ menjadi $3 \%$ hal ini mengindikasikan siswa sudah lebih mandiri dalam berpikir sehingga berkurang ketergantungannya pada guru. Aktivitas yang tidak relevan juga menyusut menjadi 4,2 \%. Seluruh data aktivitas di atas menunjukkan bahwa aktivitas belajar siswa menjadi lebih baik dari siklus I ke siklus II.

Memang harus diakui, bahwa dengan model pembelajaran kooperatif seperti yang diterapkan siswa sepertinya merasakan adanya suasana belajar yang menyenangkan (joyful learning atau learning is fun). Hal ini setidaknya terbukti dari data hasil belajar atau prestasi belajar siswa sebagaimana tersajikan pada tabel 4.2 dan Tabel 4.4 di atas dengan jelas membuktikan bahwa telah terjadi peningkatan yang sangat signifikan pada prestasi belajar siswa, dari semula hanya 23 siswa atau sebesar $65,71 \%$ yang tuntas belajar pada siklus I meningkat menjadi 31 siswa atau sebesar 87,56\% pada akhir siklus II, yang berarti mengalami peningkatan. Sementara itu untuk kategori penilaian hasil yang lain, yakni kategori siswa yang tidak tuntas, dari semula sebanyak 12 siswa $(34,28)$ yang tidak tuntas pada siklus I berkurang secara drastis menjadi hanya 4 siswa $(11,42 \%)$ yang tidak 
tuntas pada akhir siklus II, yang berarti berkurang sebesar $22,86 \%$.

Bila dilihat dari segi kriteria keberhasilan secara klasikal yang telah ditetapkan, yakni sebesar $85 \%$ dari seluruh siswa dalam kelas harus mencapai ketuntasan belajar, sementara dari penilaian hasil di akhir siklus II ini hanya menyisakan $12,44 \%$ yang tidak tuntas (yang berarti $87,56 \%$ siswa telah mencapai ketuntasan belajar), maka dari situ dapat dipahami lebih jauh bahwa tindakan guru melalui penerapan pembelajaran kooperatif tipe STAD ini telah berhasil mencapai tujuannya.

STAD didesain untuk meningkatkan rasa tanggung jawab siswa terhadap pembelajarannya sendiri dan juga pembelajaran orang lain. Siswa tidak hanya mempelajari materi yang diberikan, tetapi mereka juga harus siap memberikan dan mengajarkan materi tersebut pada anggota kelompoknya yang lain.

\section{SIMPULAN DAN SARAN}

Data-data tes hasil belajar, aktivitas belajar siswa, dan minat siswa terhadap model pembelajaran kooperatif Tipe STAD selama kegiatan belajar mengajar, kemudian dianalisis, sehingga dapat disimpulkan sesuai dengan rumusan masalah.

a. Dengan menerapkan model pembelajaran kooperatif Tipe STAD prestasi belajar siswa dari Siklus ke Siklus berikutnya mengalami peningkatan. Hasil belajar siswa pada Formatif I dan Formatif II menunjukkan 23 orang siswa tuntas secara individu, sedangkan kelas tidak tuntas. Pada Siklus II, tuntas secara individu sebanyak 31 orang siswa, sedangkan kelas adalah tuntas dengan rata-rata siklus I dan siklus II adalah 68,57 dan 85,14 .

b. Data aktivitas siswa menurut kedua pengamatan pengamat pada Siklus I antara lain: menulis/membaca (42\%), bekerja $(27 \%)$, bertanya sesama teman $(5,6 \%)$, bertanya kepada guru $(13,8 \%)$, dan yang tidak relevan dengan KBM (12\%). Dan Data aktivitas siswa menurut pengamatan pada Siklus II antara lain: menulis/membaca $(25,8 \%)$, bekerja $(52,6 \%)$, bertanya sesama teman $(14,2 \%)$, bertanya kepada guru (3\%), dan yang tidak relevan dengan $\mathrm{KBM}(4,2 \%)$.

\section{DAFTAR RUJUKAN}

Ali, Abdullah. 2003. Ilmu Alamiah Dasar. Jakarta: PT Bumi Aksara

Arikunto, Suharsimi. 2002. Prosedur Penelitian Suatu Pendekatan Praktek. Jakarta: Rineksa Cipta.

Djamarah, Syaiful Bahri. 2002. Strategi Belajar Mengajar. Jakarta: Rineksa Cipta.

Hamalik, Oemar. 1994. Metode Pendidikan. Bandung: Citra Aditya Bakti.

Joyce, Wheil, dan Calhoun. 2010. Model's of Teaching (ModelModel Pengajaran. Yogyakarta: Pustaka Pelajar.

Kemmis, S. dan Mc. Taggart, R. 1988. The Action Research Planner. Victoria Dearcin University Press.

Margono. $1997 . \quad$ Metodologi Penelitian Pendidikan. Jakarta: Rineksa Cipta. 